\title{
The use of serotonergic drugs to treat obesity - is there any hope?
}

\author{
This article was published in the following Dove Press journal: \\ Drug Design, Development and Therapy \\ 9 February 2011 \\ Number of times this article has been viewed
}

\author{
Nicholas T Bello' \\ Nu-Chu Liang ${ }^{2}$ \\ 'Department of Animal Sciences, \\ Rutgers, The State University \\ of New Jersey, New Brunswick, \\ NJ, USA; ${ }^{2}$ Department of Psychiatry \\ and Behavioral Sciences, Johns \\ Hopkins University, Baltimore, \\ MD, USA
}

\begin{abstract}
Surgical interventional strategies for the treatment of obesity are being implemented at an increasing rate. The safety and feasibility of these procedures are questionable for most overweight or obese individuals. The use of long-term pharmacotherapy options, on the other hand, can target a greater portion of the obese population and provide early intervention to help individuals maintain a healthy lifestyle to promote weight loss. Medications that act on the central serotonergic pathways have been a relative mainstay for the treatment of obesity for the last 35 years. The clinical efficacy of these drugs, however, has been encumbered by the potential for drug-associated complications. Two drugs that act, albeit by different mechanisms, on the central serotonergic system to reduce food intake and decrease body weight are sibutramine and lorcaserin. Sibutramine is a serotonin and norepinephrine reuptake inhibitor, whereas lorcaserin is a selective $5 \mathrm{HT}_{2 \mathrm{C}}$ receptor agonist. The recent worldwide withdrawal of sibutramine and FDA rejection of lorcaserin has changed the landscape not only for serotonin-based therapeutics specifically, but for obesity pharmacotherapy in general. The purpose of this review is to focus on the importance of the serotonergic system in the control of feeding and its potential as a target for obesity pharmacotherapy. Advances in refining and screening more selective receptor agonists and a better understanding of the potential off-target effects of serotonergic drugs are needed to produce beneficial pharmacotherapy.
\end{abstract}

Keywords: 5-hydroxytryptamine, serotonin 1B, fenfluramine, dexfenfluramine, satiety, dorsal raphe

\section{Introduction}

Obesity in the past several decades has become increasingly prevalent in the adult population of several countries, such as the US, Mexico, and the UK. ${ }^{1-3}$ The alarming rate of childhood obesity in these and other countries only exaggerates the health concern worldwide. ${ }^{4-6}$ In fact, the World Health Organization projects 700 million adults will be clinically obese (BMI $\geq 30$, body mass index; $\mathrm{kg} / \mathrm{m}^{2}$ ) by $2015.7,8$ Individuals who are obese or even overweight (BMI 25-29.9) are at an increased risk of developing one or more chronic diseases, including diabetes mellitus type II, coronary heart disease, hypertension, and various cancers. ${ }^{9-11}$ Several studies have indicated that weight loss, even a $5 \%$ to $10 \%$ weight reduction, either lowers the risk of developing these comorbidities or helps in their therapeutic management. ${ }^{12-16}$ The overall societal healthcare burden and the individual risk to a person's health and wellbeing caused by excessive weight gain, therefore, can be dramatically reduced by effective interventional strategies aimed at reducing body weight.
Correspondence: Nicholas T Bello Department of Animal Sciences, School of Environmental and Biological Sciences, Rutgers, The State University of New Jersey, 84 Lipman Drive, New Brunswick, NJ 0890 I, USA

Tel +l 7329322966

Fax +I 7329326996

Email ntbello@rci.rutgers.edu submit your manuscript | www.dovepress.com

Dovepress

DOI: | 0.2147/DDDT.SI 1859 which permits unrestricted noncommercial use, provided the original work is properly cited. 
The type and degree of interventional strategies recommended by a clinician to treat obesity can vary depending on the severity of weight gain and obesity-related complications. The initial approach involves having patients reduce their total caloric intake by eating more nutritious foods while increasing their physical activity. Other behavioral approaches may involve self-monitoring of eating behaviors, cognitive therapies, and lifestyle modification support. ${ }^{12}$ In addition, pharmacotherapy can be initiated if moderately overweight individuals (BMI 27-29.9) have difficulty losing weight or are at a high risk for developing an obesity-related comorbidity. Pharmacotherapy is typically initiated in obese individuals with a BMI of $\geq 30$ as part of a comprehensive treatment approach. ${ }^{12,17}$ In more severe obese individuals with a BMI of $>40$ (also known as class III obese) or a BMI $>35$ with one or more obesity-related comorbidities, bariatric surgical options are considered as well. ${ }^{12,13,18,19}$ Bariatric surgery, in particular gastric bypass, compared with other interventional strategies is the most clinically effective at decreasing body weight and reducing the incidence and risk of most obesity-related comorbidities. ${ }^{19-21}$ Bariatric surgery, however, poses a mortality risk (as high as $10 \%$ ) to patients undergoing the procedure and the immediate and the long-term cost-effectiveness is only significantly apparent in individuals with a $\mathrm{BMI} \geq 40 .^{22-24}$ In addition, there is a suggested higher risk of suicide in patients undergoing bariatric surgery. A recent survey of 16,683 bariatric operations found there were 31 suicides in the 3 -year post-surgery period (13.7 per 10,000 among men and 5.2 per 10,000 among women), which is a much higher rate than general age and sex-matched population in the US (2.4 per 10,000 among men and 0.7 per 10,000 among women). ${ }^{25}$ Nonetheless, obese individuals with a BMI $\geq 40$ represent only $10 \%$ to $12 \%$ of the adult overweight or obese population in the US, suggesting that bariatric surgery is not a feasible weight loss interventional strategy for most of the afflicted population. ${ }^{26}$ Hence, overweight or moderately obese individuals would benefit tremendously from effective pharmacotherapy before their weight gain becomes unmanageable or they develop associated comorbidities. When combined with other interventional strategies, in this sense, pharmacotherapy can help achieve or maintain ideal weight loss and possibly avoid more invasive life-threatening surgical interventions.

The development of effective long-term pharmacotherapy for obesity is a difficult task because mechanisms that promote sustained weight loss are often accompanied by mild to severe adverse events. The purpose of this review is to primarily focus on two obesity medications, sibutramine and lorcaserin, which act on the central serotonergic systems to reduce body weight. While the relevance of pharmacotherapy for obesity is certain to change in the next few years, particularly as a consequence of the withdrawal of sibutramine and an FDA advisory panel's concerns over lorcaserin, this review will highlight the importance of serotonergic systems and the pharmacotherapy potential for serotonergic drugs in the long-term treatment of obesity.

\section{Pharmacotherapy for the long-term treatment of obesity}

The clinical endpoint for effective pharmacotherapy, as stipulated by the Food and Drug Administration (FDA, USA) and National Institute for Health and Clinical Excellence (NICE, UK), is based on mean efficacy and categorical efficacy. Mean efficacy is defined as a medication-associated (ie, greater than placebo) weight reduction of $5 \%$. Categorical efficacy is defined as a significantly greater proportion (at least 35\%) of those individuals receiving the medication compared with placebo controls maintaining a $5 \%$ weight loss from their initial weight. ${ }^{13,27}$ A mean efficacy of a $5 \%$ medication-associated weight reduction has been a difficult criterion to achieve in most large scale clinical trials and an overall efficacy of a medication is generally assessed more by a risk-benefit approach. Until fall 2010, the only two prescribed medications for the long-term treatment of obesity were orlistat and sibutramine. These drugs have completely different mechanisms of action, but each has shown to produce a varying degree of clinical efficacy at reducing body weight when administered along with interventional strategies aimed at changing a patient's diet, physical activity, and eating behaviors.

Orlistat or tetrahydrolipstatin is a derivative of lipstatin, an inhibitor of lipases isolated from the Gram-positive bacterium Streptomyces toxytricini. ${ }^{28}$ Orlistat reduces the absorption of dietary fat by selectively and irreversibly binding to pancreatic and gastric lipases in the intestinal lumen. Inhibition of these lipases prevents the breakdown of triglycerides and diacylglycerides into free fatty acids for epithelial absorption and subsequent utilization. ${ }^{29}$ Orlistat (120 mg 3 times daily) reduces the absorption of dietary fat by approximately $30 \%$ and has been demonstrated to result in an approximately $3 \%$ greater orlistat-associated reduction in body weight in long-term (52-week) randomized double-blinded studies. ${ }^{30-32}$ The most commonly reported adverse events with orlistat treatment in a large number of subjects (as high as 30\% above the control group) were related to mild to moderate gastrointestinal disturbances..$^{30}$ Aside from rare cases of 
acute liver injury, orlistat is a moderately well-tolerated, relatively safe drug producing modest long-term weight loss. ${ }^{33}$ A similar favorable assessment of orlistat's risk-benefit analysis is shared by drug regulatory agencies in the US, European Union, and Australia, which have all approved over-the-counter dosages of the drug. ${ }^{33-35}$

Sibutramine, on the other hand, was indefinitely suspended in August 2010 for the treatment of obesity by the European Union drug regulatory agency based on several reports of cardiovascular complications; the agency cited the "drug's benefits do not outweigh the risks" ${ }^{36}$ In October 2010, following the findings of a comprehensive study examining the potential cardiovascular risks and a split decision of an FDA advisory panel, Abbott Laboratories, the manufacturers of sibutramine, withdrew sibutramine from the US, Australia, and other countries. ${ }^{37}$ Sibutramine is in a class of drugs known as monoamine reuptake inhibitors and most drugs of this class are prescribed for the treatment of depression. ${ }^{38-40}$ The effectiveness of monoamine reuptake inhibitors is achieved by augmenting central nervous system (CNS) concentrations of monoamine neurotransmitters, such as dopamine (DA), norepinephrine (NE), and serotonin (5-hydroxytryptamine; 5HT). Sibutramine was ineffective in vivo as an antidepressant, but produced sustained weight loss by reducing food intake and increasing energy expenditure. . $^{38,41}$ Sibutramine and its active amine metabolites alter serotonergic and noradrenergic, but not dopaminergic, activity in brain areas that are involved in the control of appetite. ${ }^{38,42,43}$ Long-term treatment ( $\sim 52$ weeks) with sibutramine (10 or $15 \mathrm{mg}$ once daily) in randomized placebo-controlled studies has been shown to reduce body weight by $5 \%$ to $10 \%$ more than placebo control subjects. ${ }^{44,45}$ A meta-analysis examining 10 long-term weight-loss studies with sibutramine $(15 \mathrm{mg}$ once daily), however, found more modest weight loss, with a $4.3 \%$ sibutramine-associated reduction in body weight. ${ }^{17}$ Since its FDA approval in 1997, the widespread use of sibutramine to treat obesity was limited because the drug increased heart rate and blood pressure and was not indicated in obese or overweight patients with a history of cardiovascular disease. ${ }^{46,47}$ Prompting the withdrawal of sibutramine was a recently completed multicenter trial examining sibutramine on cardiovascular OUTcomes (SCOUT) in subjects with either a history of at least one risk factor for cardiovascular disease. The findings from this study demonstrated an overall $16 \%$ increase in the relative risk of cardiovascular events (ie, nonfatal myocardial infarction and stroke) with sibutramine treatment. Moreover, the sibutramine-associated weight loss at the end of the trial was modest, with approximately
$3 \%$ greater weight loss than the placebo group..$^{48}$ The small weight-loss benefit and increased risk of cardiovascular events in at risk obese patients in such a large study led to an unfavorable assessment by an FDA advisory panel and subsequent withdrawal of the medication.

Lorcaserin (ADP356) is another potential treatment for obesity that acts on the central serotonergic system to reduce food intake and body weight. Lorcaserin is a selective serotonin receptor $\left(5 \mathrm{HT}_{2 \mathrm{C}}\right)$ agonist and is believed to reduce food intake predominantly by influencing hypothalamic pathways involved in appetite. ${ }^{49} \mathrm{In}$ a phase III clinical trial with 3182 overweight or obese subjects (known as BLOOM; Behavioral modification and Lorcaserin for Overweight and Obesity Management), there was a $4 \%$ lorcaserin (10 $\mathrm{mg}$ twice daily)-associated weight reduction at 52 weeks. Despite this modest weight loss, lorcaserin was associated with few subject-reported and no cardiovascular-related adverse events. ${ }^{50}$ The toxicology data in rodents presented to the FDA advisory panel, however, demonstrated a significant number of neoplasms in mammary and brain tissue of rats treated with lorcaserin $\left(10 \mathrm{mg} / \mathrm{kg}, 30 \mathrm{mg} / \mathrm{kg}, 100 \mathrm{mg} / \mathrm{kg}\right.$ per day) for 2 years..$^{51}$ Based on the modest weight loss and the problematic carcinogenicity findings, the FDA advisory panel recommended that lorcaserin not be approved for the long-term treatment of obesity, and that decision was supported by the FDA's complete response letter to the New Drug Application (NDA) filed for lorcaserin, which requested more data addressing these issues. ${ }^{52}$

\section{Serotonin in the control of feeding behavior and metabolism}

Serotonin (5HT) was initially isolated from beef serum in 1948 during the process of determining an active substance involved in vasoconstriction. ${ }^{53,54}$ Although $5 \mathrm{HT}$ has extensive biological actions in peripheral tissue and as a vasoactive amine, its role as a neurotransmitter in the CNS as a modulator of behavior and mood has received considerable attention. ${ }^{55}$ The 5HT-containing neurons are organized into nine nuclei (B1-B9) and are located in the midbrain and hindbrain areas. The dorsal raphe (B7), in particular, is a midbrain nucleus that contains a substantial portion of the total brain 5HT and has distinct projections to hypothalamic nuclei and other feeding-related forebrain areas. ${ }^{56,57}$ Obesity, either by genetic or diet-induced means, has been demonstrated to alter 5HT dorsal raphe neurons and 5HT terminal regions. For instance, the genetic obese fatty Zucker rats were shown to have hyperexcitable dorsal raphe neurons and greater 
feeding-induced hypothalamic 5HT levels compared with lean Zucker rats ${ }^{58,59}$ Continuous infusions (14-day) of 5HT into a target hypothalamic region, ventromedial nucleus, has been shown to reduce food intake and body weight of lean Zucker rats, but not obese Zucker rats. ${ }^{60}$ Related to this, increases in 5HT transporter binding have been reported in the dorsal raphe of rats made obese by feeding a high-energy diet $(68 \%$ carbohydrate and $13 \%$ fat) for 7 weeks. Taken together, these data suggest a dysregulation of central serotonergic pathways as a consequence of obesity. ${ }^{61}$

The direct functional involvement of 5HT in the modulation of feeding behavior was suggested by early experiments examining the anorectic potency of fenfluramine. ${ }^{62,63}$ Fenfluramine (3-trifluoromethyl-N-ethylamphetamine) is structurally similar to $d$-amphetamine, but fenfluramine is more potent as an anorectic agent without an abuse potential. ${ }^{64-66}$ Fenfluramine is a racemic compound with its active enantiomer being the $d$-isomer or dexfenfluramine. ${ }^{67}$ The mechanism of action for dexfenfluramine is the release of 5HT (and to a much lesser extent NE), whereas amphetamine is less selective and releases NE and DA from nerve terminals. Fenfluramine, dexfenfluramine, and $d$-amphetamine are classified as monoamine releasing agents, but specifically are transporter substrates causing the displacement of monoamines from intracellular storage independent of neuronal activity. ${ }^{40,62,68}$ In addition, active metabolites of fenfluramine and dexfenfluramine (eg, nor-fenfluramines) act as agonists at postsynaptic serotonin receptors to potentiate the serotonergic actions of the parent drugs. ${ }^{66,69}$ Dexfenfluramine also has actions to enhance energy expenditure since the body weight produced by the drug is greater than that achieved by pair-feeding animals. ${ }^{65,70,71}$ This enhanced energy expenditure partly occurs via increased fat oxidation. ${ }^{72}$ Fenfluramine was approved in 1973 and dexfenfluramine was approved in 1996 as medications for treatment of obesity in the US. Fenfluramine and later dexfenfluramine were part of an "off-label" combinational drug therapy with phentermine, an amphetamine analog stimulant FDAapproved for the short-term (up to 3 months) treatment of obesity, and the drug combination was known as "fen-phen" or "dexfen-phen". ${ }^{66,73}$ Although the combinational therapies were effective in the long-term management (up to 12 months) of obesity and were widely prescribed, the therapies were associated with a significant increased risk of developing primary pulmonary hypertension and valvular heart disease. ${ }^{74-80}$ These adverse events were discovered to be caused by fenfluramine and dexfenfluramine and the two drugs were subsequently withdrawn from the market in 1997 at the FDA's recommendation. ${ }^{81}$
Not only did experimental findings with fenfluramine and dexfenfluramine suggest that targeting the serotonergic systems produced clinically significant body weight reductions, these drugs also implicated 5HT's involvement in the inhibitory control of eating. Acute peripheral injections of fenfluramine and dexfenfluramine have been demonstrated to increase hypothalamic concentrations $5 \mathrm{HT}^{82,83}$ Also, when dexfenfluramine is chronically administered to rodents it reduces meal sizes and meal duration, and progresses the behavioral sequence of satiety, suggesting that the drug acts on the physiological functions involved in the normal cessation of a meal. ${ }^{84-86}$ That is, when rats are allowed to eat until satiety they display a temporal sequence of behaviors as meal consumption is terminating that begins with a reduction in eating followed by increases in grooming and other activities, and then a period of rest. ${ }^{84,85,87}$ This behavioral sequence is disrupted with amphetamine and food adulterated with bittertasting quinine, suggesting the anorectic responses produced by these agents are mediated differently from those involved with satiety. ${ }^{85,88}$ Generally speaking, it has been demonstrated that serotonergic compounds, which specifically and dosedependently increase 5HT signaling to reduce food intake, maintain the integrity of the behavioral satiety sequence at a related range of doses. ${ }^{84,85,89}$ Similar reductions in eating rate and increased subjective satiety ratings have been demonstrated in human subjects administered fenfluramine and other serotonergic drugs, confirming the behavior interpretations made in rodents. ${ }^{70,90-92}$ Correspondingly, certain pharmacological conditions that decrease CNS levels of 5-HT promote overeating. ${ }^{57}$ Centrally injected selective serotonin depleting agents, such as $p$-chlorophenylalanine or 5,7-dihydroxytryptamine pretreatment with desmethlyimipramine, resulted in pronounced hyperphagia and increased body weight in rats..$^{93,94}$

Sibutramine was approved for the long-term treatment of obesity by the FDA in November 1997 (coincidentally, dexfenfluramine was withdrawn in September, 1997). Sibutramine also increases the extracellular 5HT to reduce food intake, but does so by a different mechanism of action than dexfenfluramine. Acting as a NE and 5HT reuptake inhibitor, sibutramine (and its active metabolites) prevents the extracellular removal of monoamines and their effectiveness, and therefore is dependent on neuronal activity of 5HT neurons. Using anorectic doses of fenfluramine or sibutramine in rats, the magnitude of release of 5HT in the hypothalamus was shown to be 10 - to 15 -fold higher with fenfluramine $(3 \mathrm{mg} / \mathrm{kg})$ than with sibutramine $(10 \mathrm{mg} / \mathrm{kg}) .{ }^{82}$ The reduced magnitude of $5 \mathrm{HT}$ release with sibutramine is mediated, in 
part, by indirect activation of somatodendritic autoreceptors, which modulate the intrinsic activity of 5HT neurons. ${ }^{82,95}$ This autoreceptor inhibition is not evident with monoamine releasers (eg, fenfluramine or dexfenfluramine) because their mechanism of action is not dependent on neuronal activation. ${ }^{82}$ Sibutramine, similar to serotonin-selective reuptake inhibitors (SSRI), was believed to mediate its actions by increases in basal or tonic levels of 5HT with repeated treatment. It appears that autoreceptor desensitization in the dorsal raphe rather than increased 5HT actions in the terminal is more likely involved in the sustained actions of SSRIs, but this needs further delineation for the anorectic actions of sibutramine. ${ }^{38,96,97}$ It is worth noting that SSRIs do not have a sustained effect on weight loss, hence it has been concluded that the combined actions on the 5HT and $\mathrm{NE}$ transporters are needed for the weight loss efficacy of sibutramine. ${ }^{39,98,99}$

Sibutramine has been reported to improve glucose regulation and lipid profiles in obese subjects, but the enhancement of these factors appears to be a consequence of weight loss rather than the direct actions of sibutramine on metabolism. ${ }^{38,100}$ Sibutramine has been demonstrated, however, to improve obesity-related energy expenditure. Dietary weight loss is accompanied by a decrease in energy expenditure, which tends to be an obstacle for optimal weight loss. ${ }^{101}$ Several studies have indicated that sibutramine attenuates the decline in energy expenditure that follows weight loss. ${ }^{102,103}$ The increased energy expenditure has been shown to be mediated by central modulation of sympathetic outflow, the thermogenic effects being blocked by antagonism of $\beta_{3}$ adrenoceptor in rats. ${ }^{104}$ On the other hand, the effect of sibutramine on heart rate and blood pressure appears to be a paradoxical interplay between reduced central and increased peripheral sympathetic regulation, but this needs further clarification. ${ }^{56,105-108}$

The assortment of central and peripheral biological actions of 5HT is mediated by at least 14 different classified receptors that are differentiated based on structure, function, and intracellular signaling. ${ }^{109,110}$ The two receptors most critically involved in the control of feeding behavior and body weight homeostasis are the $5 \mathrm{HT}_{1 \mathrm{~B}}$ and $5 \mathrm{HT}_{2 \mathrm{C}}$ receptors. ${ }^{111}$ Recent findings have also implicated $5 \mathrm{HT}_{2 \mathrm{~B}}$ receptors in the anorectic properties of dexfenfluramine; however, this receptor has been strongly implicated in the cardiopulmonary adverse effects of dexfenfluramine. ${ }^{112-114}$ The role of the $5 \mathrm{HT}_{2 \mathrm{~B}}$ receptor is likely to be a mechanism involved in potentiating 5HT release from serotonergic neurons, but its feasibility as a target for obesity certainly requires further examination. ${ }^{112}$
The $5 \mathrm{HT}_{1 \mathrm{~B}}$ receptor (classified at one time as the human $5 \mathrm{HT}_{1 \mathrm{D \beta}}$ receptor ${ }^{115,116}$ ) is a G-protein couple receptor (GPCR) that negatively couples to adenylyl cyclase to inhibit cAMP formation. Like receptors of the $5 \mathrm{HT}_{1}$ class, the $5 \mathrm{HT}_{1 \mathrm{~B}}$ receptor has a high affinity for $5 \mathrm{HT}$ and is encoded by a gene sequence without introns. ${ }^{110}$ Located on nerve terminals, the $5 \mathrm{HT}_{1 \mathrm{~B}}$ receptor functions as an autoreceptor to inhibit the release of 5HT from serotonergic neurons or as heteroreceptors to inhibit the release of other (nonserotonin) neurotransmitters. ${ }^{109,110,117}$ The involvement of the $5 \mathrm{HT}_{1 \mathrm{~B}}$ receptor in feeding behavior was initially implicated using preferential antagonists with affinity for the receptor, such as (+/-) cyanopindolol and methiothepin, to block the anorectic actions of dexfenfluramine, whereas the selective agonist, CPP94235 (3-(1,2,5,6-tetrahydro-4pyridyl)-5-propoxypyrrolo[3, 2-b] pyridine), reduced meal size and decreased feeding duration. ${ }^{118-121}$ Further evidence for a role in feeding behavior was demonstrated with the generation of the $5 \mathrm{HT}_{1 \mathrm{~B}}$ receptor knockout mouse. Following administration of fenfluramine ( 3 or $10 \mathrm{mg} / \mathrm{kg}$ ), for instance, $5 \mathrm{HT}_{1 \mathrm{~B}}$ receptor knockout mice were unresponsive to its anorectic actions and demonstrated reduced or no neuronal activation in feeding related brain areas compared with wild types. ${ }^{122}$ It also has been reported that $5 \mathrm{HT}_{1 \mathrm{~B}}$ receptor knockout mice, compared with age-matched wild type mice, have higher body weights and consumed more food and water, but these findings are not consistently reported with $5 \mathrm{HT}_{1 \mathrm{~B}}$ knockout mice. ${ }^{122,123}$

The actions of the $5 \mathrm{HT}_{1 \mathrm{~B}}$ receptor in the $\mathrm{CNS}$ have been demonstrated to directly influence pathways involved in food intake and body weight homeostasis. Separate populations of neurons in arcuate nucleus (ARC) of the hypothalamus express the orexigenic peptides neuropeptide Y/agouti-related peptide (NPY/AgRP) or the precursor pro-opiomelanocortin (POMC) to the anorectic peptide alpha-melanocyte stimulating hormone ( $\alpha$-MSH). These two groups of neurons are activated or inhibited by other CNS pathways or peripheral circulating factors to control feeding behavior and energy expenditure. For example, the POMCcontaining neurons release $\alpha-\mathrm{MSH}$ to acts on melanocortin (MC) MC3/MC4 receptors lead to downstream effects that reduce food intake and increase energy expenditure. Reciprocally, increases in food intake and reduction in energy expenditures are demonstrated following activation of adjacent NPY/AgRP neurons. While NPY acts on a distinct set of receptors, $\mathrm{AgRP}$ is an endogenous antagonist for $\mathrm{MC} 3 / \mathrm{MC} 4$ receptors. ${ }^{124-127}$ In a series of experiments it was determined $5 \mathrm{HT}_{1 \mathrm{~B}}$ receptors are expressed on AgRP neurons and 5HT 
terminals are in close proximity to ARC neurons that contain AgRP. Furthermore, it was demonstrated that CPP 94235, a selective $5 \mathrm{HT}_{1 \mathrm{~B}}$ receptor agonist, reduces the membrane potential (ie, hyperpolarizes) of ARC neurons that express NPY/AgRP and reduces the inhibitory inputs on POMC neurons. ${ }^{128}$ Moreover, mice with disruptions in the MC4 receptor were unresponsive to the anorectic effects of dexfenfluramine or CPP 94253. ${ }^{128}$ Such data strongly suggest that 5HT actions are mediated by the $5 \mathrm{HT}_{1 \mathrm{~B}}$ receptor signaling to increase the MC4 receptor-mediated melanocortin pathways.

In contrast to the $5 \mathrm{HT}_{1 \mathrm{~B}}$ receptor, the $5 \mathrm{HT}_{2 \mathrm{C}}$ receptor is a GPCR with cellular excitatory activation that leads to the accumulation of inositol phosphates and downstream activation of phospholipase $\mathrm{C}$. Originally classified as the $5 \mathrm{HT}_{1 \mathrm{C}}$ receptor based on its binding affinities for $5 \mathrm{HT}$, the receptor was re-classified as $5 \mathrm{HT}_{2 \mathrm{C}}$ after gene sequencing revealed it had introns in various coding regions and was structurally and functionally similar to receptors in the $5 \mathrm{HT}_{2}$ class. ${ }^{110}$ Similar to $5 \mathrm{HT}_{1 \mathrm{~B}}$, the role of the $5 \mathrm{HT}_{2 \mathrm{C}}$ receptor was implicated in feeding by several experiments using preferential and selective agonist and antagonists. ${ }^{120,129,130}$ Experiments utilizing $5 \mathrm{HT}_{2 \mathrm{C}}$ receptor knockout mice have demonstrated hyperphagia and an obese phenotype. ${ }^{131-133}$ These mice also are less responsive to the anorectic properties of dexfenfluramine $(3 \mathrm{mg} / \mathrm{kg})$ and preferentially selective agonists. ${ }^{132,134}$ It has been shown that the $5 \mathrm{HT}_{2 \mathrm{C}}$ receptor mediates the activity of ARC neurons, in a mechanism that is complementary to that of the $5 \mathrm{HT}_{1 \mathrm{~B}}$ receptor. For instance in the $\mathrm{ARC}$, the $5 \mathrm{HT}_{2 \mathrm{C}}$ receptor was also found in up to $80 \%$ of POMC neurons and activation of the $5 \mathrm{HT}_{2 \mathrm{C}}$ receptor increased the firing rate of POMC neurons. Upstream activation of $\mathrm{MC}$ receptors was also needed because dexfenfluramine action can be blocked by antagonism of $\mathrm{MC} 3 / \mathrm{MC} 4$ receptors, while the anorectic responses of MTII, an MC3/MC4 receptor agonist, were indistinguishable between wild type and $5 \mathrm{HT}_{2 \mathrm{C}}$ receptors knockout mice. ${ }^{135}$ Together with the findings for the $5 \mathrm{HT}_{1 \mathrm{~B}}$ receptor, this suggests that $5 \mathrm{HT}$ activates POMC neuron and inhibits NPY/AGRP to reduce the expression of feeding behaviors. Such findings support the pharmacological studies that suggest that the $5 \mathrm{HT}_{1 \mathrm{~B}}$ and $5 \mathrm{HT}_{2 \mathrm{C}}$ receptors reduce food intake by independent mechanisms. ${ }^{136}$

Serotonin has also been implicated in glucose regulation by action at the $5 \mathrm{HT}_{2 \mathrm{C}}$ receptor. Early findings with $5 \mathrm{HT}_{2 \mathrm{C}}$ receptor knockout mice indicated that these animals had elevated fasted blood glucose and insulin levels and impaired glucose tolerance compared with wild types. ${ }^{133}$ Using the preferential, mCPP (m-chlorophenyl-piperazine), or the selective, BVT.X, $5 \mathrm{HT}_{2 \mathrm{C}}$ ligands, it was demonstrated that
$5 \mathrm{HT}_{2 \mathrm{C}}$ receptor compounds improved glucose homeostasis in diet-induced or mutant obese animals. This was accomplished by using low doses of the compounds, which did not affect food intake. The mechanisms were shown to be mediated by activation of POMC neurons and of downstream activation of MC4 receptors located in the intermediolateral cell nucleus of the spinal cord, suggesting $5 \mathrm{HT}_{2 \mathrm{C}}$ receptor agonist alters sympathetic outflow to improve glucose homeostasis. ${ }^{137}$ A similar mechanisms of MC4 activation to increase sympathetic outflow is speculated to account for the hyperthermic effects noted with several selective $5 \mathrm{HT}_{2 \mathrm{C}}$ receptor agonists, but this has not been experimentally determined. ${ }^{138,139}$ Lorcaserin (APD-356), a $5 \mathrm{HT}_{2 \mathrm{C}}$ agonist, has not only completed a phase III study to determine effectiveness for the treatment of obesity (BLOOM), but is also undergoing a phase III study for the management of obesity and glucose regulation outcomes in subjects with diabetes mellitus type II (BLOOM-DM). ${ }^{51}$ Preliminary findings indicate improvements in fasting blood glucose levels and $\mathrm{HbA}_{1 \mathrm{c}}$ levels in obese diabetic subjects treated with lorcaserin (10 mg twice daily). ${ }^{140}$

\section{Chemistry and related pharmacology of sibutramine and lorcaserin}

Sibutramine hydrochloride (BTS 54 524; N-1-(1[4-chlorophenyl]cyclobutyl)-3-methylbutyl-N,Ndimethylamine hydrochloride monohydrate) is a racemic compound that is structurally similar to other $\beta$-phenylethylamine drugs, such as metamphetamine, phentermine, and dexfenfluramine (see Figure 1). ${ }^{41,141}$ It is suggested that the chlorine on the 4 position of the phenyl

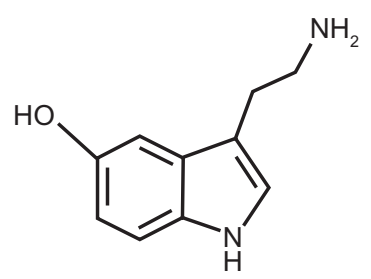

Serotonin $(5 \mathrm{HT})$

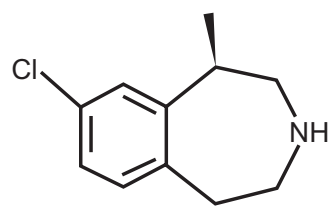

Lorcaserin

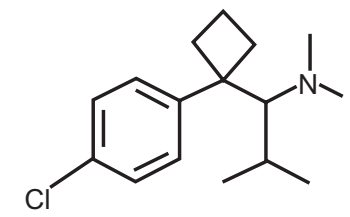

Sibutramine

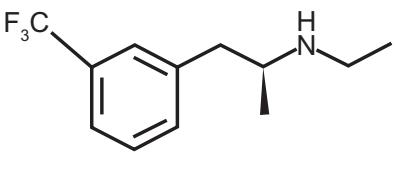

Dexfenfluramine
Figure I Chemical structure of serotonin (5-hydroxytryptamine; 5HT) and serotonergic compounds that have been used for, or have the potential to treat, obesity. 
ring imparts affinity for the serotonin transporter, since it has been demonstrated that a halogenated-substituted phenyl rings is needed for SSRI specificity. ${ }^{142}$ In vitro and in vivo data have demonstrated that sibutramine weakly inhibits monoamine uptake in human and rat tissue. ${ }^{40,143,144}$ For instance, in vitro inhibition (half maximal inhibitory concentration, $\left.\mathrm{IC}_{50}\right)$ in rat brain tissue of sibutramine is $2.17 \mu \mathrm{M}$ for NE, $477 \mu \mathrm{M}$ for $5 \mathrm{HT}$, and $10.8 \mu \mathrm{M}$ for DA. ${ }^{143}$ Sibutramine, though, is metabolized by the liver primarily by the P450 isozyme CYP2B6 into two active metabolites that are more potent monoamine inhibitors than the parent compound..$^{40,143-145}$ Sibutramine metabolism takes place by a series of demethylations, first to the primary (M1) metabolite (BTS 54 354; N-1-(1-[4-chlorophenyl] cyclobutyl]-3methylbutyl-N-methylamine hydrochloride monohydrate) and then to secondary (M2) metabolite (BTS 54 505; N-1-(1-[4chlorophenyl] cyclobutyl]-3-methylbutylamine hydrochloride monohydrate). The M1 metabolite demonstrated an in vitro inhibition of $0.14 \mu \mathrm{M}$ for NE, $3.9 \mu \mathrm{M}$ for $5 \mathrm{HT}$, and $0.16 \mu \mathrm{M}$ for DA, whereas the M2 metabolite in vitro inhibition was $0.06 \mu \mathrm{M}$ for NE, $5.1 \mu \mathrm{M}$ for $5 \mathrm{HT}$, and $0.31 \mu \mathrm{M}$ for DA. ${ }^{143}$ In vivo data indicate the two active metabolites of sibutramine are approximately equipotent for $\mathrm{NE}$ and 5HT inhibition with inactive inhibition for DA. ${ }^{40,143}$ The active metabolites display a similar degree of inhibition for 5HT as SSRI compounds. ${ }^{40,83}$ In humans the elimination half-life of oral administration of sibutramine is 1.1 hours while the half-lives of the active metabolites are much longer, at 14 hours and 16 hours for M1 and M2, respectively. ${ }^{146}$ In a recent positron emission tomography study in human subjects $(n=11)$, it was determined that brain serotonin transporter occupancy was significantly positively correlated $\left(r^{2}=0.59, P=0.003\right)$ with plasma M2 levels, suggesting that 5HT inhibition is mediated predominately by $\mathrm{M} 2 .{ }^{147}$

Lorcaserin hydrochloride [(1R)-8-chloro-2,3,4,5 tetrahydro-1-methyl-1H-3-benzazepine] is a substituted 3-benzazepine, structurally resembling serotonin and nor-dexfenfluramine (dexfenfluramine metabolite). The compound is synthesized from a substituted phenylethylamine precursor with the chlorine substitution at the 8-position yielding high affinity and selectivity for the $5 \mathrm{HT}_{2 \mathrm{C}}$ receptor. ${ }^{148}$ In fact, lorcaserin demonstrated $\sim 10$-fold higher affinity for the human $5 \mathrm{HT}_{2 \mathrm{C}}$ receptor compared with the $5 \mathrm{HT}_{2 \mathrm{~A}}$ and $5 \mathrm{HT}_{2 \mathrm{~B}}$ receptors $\left(\mathrm{K}_{\mathrm{i}}\right.$ values of $15 \mathrm{nM}$, $112 \mathrm{nM}$, and $174 \mathrm{nM}$, respectively) and $>40$-fold higher affinity compared with other 5 HT receptors. ${ }^{149}$ Using in vitro functional assays examining inositol phosphate accumulation in HEK cells transfected with specific human 5HT receptors, lorcaserin was 18-fold and 104-fold more potent at the $5 \mathrm{HT}_{2 \mathrm{C}}$ than at the $5 \mathrm{HT}_{2 \mathrm{~A}}$ and $5 \mathrm{HT}_{2 \mathrm{~B}}$ receptors, respectively. ${ }^{149}$ Lorcaserin is metabolized by the liver and the M1 metabolite is a sulfamate, which is inactive with no apparent affinity for any of the $5 \mathrm{HT}_{2}$ receptors. ${ }^{149,150}$ The elimination half-life of orally administered lorcaserin in humans is 11.1 hours and the half-life of the M1 metabolite is 41.3 hours. $^{51}$

\section{Clinical efficacy studies for sibutramine and lorcaserin}

The efficacy of sibutramine for weight loss with diet intervention was tested in several clinical trials in obese subjects. In one double-blind randomized trial, sibutramine at $5 \mathrm{mg}$ or $20 \mathrm{mg}$ once daily was compared with placebo in 3 groups of subjects. Notably, medications were administered over an 8-week period during the holiday season with Thanksgiving falling between week 2 and 3 , Christmas between week 6 and 7, and New Year's falling on weeks 7 and 8. Weight loss in the $5 \mathrm{mg}$ sibutramine group $(\mathrm{n}=18)$ was approximately $2 \%$ greater than in the placebo group $(\mathrm{n}=19)$, while weight loss in the $20 \mathrm{mg}$ sibutramine group $(\mathrm{n}=18)$ was approximately $4 \%$ greater than in placebo. ${ }^{151}$ In another multi-center double-blind randomized study using a wider dose range of sibutramine ( 6 doses between 1 and $30 \mathrm{mg}$ once daily) in a large sample size $(n=1043)$ for a longer duration ( 24 weeks) the efficacy of sibutramine was further assessed. There was a dose-dependent relationship for weight loss with sibutramine over the trial. Doses of $1 \mathrm{mg}$ or $5 \mathrm{mg}$ produced an approximately $2 \%$ greater weight loss than in those individuals receiving placebo, while doses of $10 \mathrm{mg}, 15 \mathrm{mg}, 20 \mathrm{mg}$, and $30 \mathrm{mg}$ produced an approximately $4 \%$ to $7 \%$ greater weight loss than in placebo. The categorical efficacy with 10 to $30 \mathrm{mg}$ of sibutramine demonstrated that $>58 \%$ of the population maintained 5\% weight loss from baseline and $>17 \%$ of the population maintained $10 \%$ weight loss from baseline over the 24 weeks. After the 24-week treatments there was a single-blind phase "washout" period of 6 weeks during which placebo was administered to all subjects. At the end of this period subjects regained weight, those losing the most during treatment regaining the most weight during the washout period. ${ }^{152}$ In a smaller study $(n=173)$ conducted in the same fashion, after a 6-week washout period from 24 weeks of sibutramine treatment $\geq 40 \%$ of the subjects from the 10 - to 30 -mg sibutramine group maintained a $5 \%$ weight loss from baseline and $\geq 12 \%$ maintained a $10 \%$ weight loss from baseline. ${ }^{153}$ The greatest amount of weight loss with sibutramine appears to occur during the first 12 weeks of treatment, weight stabilizing or increasing slightly with longer treatment. ${ }^{17,45,48,152}$ 
In a meta-analysis that examined the data from 10 double-blind randomized control studies $(n=2623)$ it was revealed that long-term treatment (1 year or more) with sibutramine (10-20 mg once daily) lost $3.7 \%$ to $5.0 \%$ more weight than individuals receiving placebo. In addition, from the same data set, approximately $35 \%$ more individuals receiving sibutramine than subjects receiving placebo maintained $a \geq 5 \%$ weight loss and $18 \%$ more than placebo maintained $\mathrm{a} \geq 10 \%$ weight loss from baseline. In comparison, data from 13 studies $(n=4948)$ found that the FDA-approved gastrointestinal lipase inhibitor orlistat produced a weight loss $2.9 \%$ to $3.4 \%$ greater than in individuals receiving placebo. Proportionally, only approximately $21 \%$ more individuals taking orlistat maintained $\mathrm{a} \geq 5 \%$ weight loss and approximately $12 \%$ maintained a $\geq 10 \%$ weight loss from baseline. ${ }^{17}$ Sibutramine was also more effective at reducing body weight directly compared with another serotonergic drug used to treat obesity, dexfenfluramine. This comparison was only with a single dose of both drugs, rather than a range of doses. For this study, 2 groups of obese subjects received either sibutramine (10 $\mathrm{mg}$ once daily; $\mathrm{n}=112$ ) or dexfenfluramine (15 mg twice daily; $\mathrm{n}=114$ ) for 12 weeks. Because there was no placebo control group, weight loss was compared with baseline values within groups. Sibutramine treatment produced a $5.4 \%$ weight loss, dexfenfluramine a $4.2 \%$ weight loss. Sibutramine was also associated with a greater proportion of subjects maintaining a $\geq 5 \%$ weight loss for the study duration, (46\% compared with $34 \%$ for dexfenfluramine). ${ }^{154}$

The first double-blind placebo controlled randomized clinical trial for lorcaserin examined the efficacy of three doses (10 mg or $15 \mathrm{mg}$ once daily, $10 \mathrm{mg}$ twice daily) in obese individuals $(\mathrm{n}=469)$ for 12 weeks. For this study no diet or lifestyle intervention strategy was endorsed by the experimenters for the study participants. Lorcaserin produced a dosedependent reduction in weight, with a $1.4 \%, 2.3 \%$, and $3.1 \%$ greater weight loss than placebo for the $10 \mathrm{mg}$ (once daily), $15 \mathrm{mg}$ (once daily), and $10 \mathrm{mg}$ (twice daily) doses, respectively. The proportion of subjects losing $\geq 5 \%$ body weight from baseline was $12.8 \%$ (10 mg once daily), $19.5 \%$ (15 mg once daily), and $31.2 \%$ (10 mg twice daily). ${ }^{150}$ In a multicenter double-blind placebo-controlled randomized clinical trial in a larger number of obese subjects $(n=3182)$, the efficacy of lorcaserin (10 mg twice daily) was compared with placebo for 1 to 2 years. In addition to including diet and lifestyle interventional strategies, the efficacy of lorcaserin was further assessed by having a randomized portion of subjects in lorcaserin groups reassigned to placebo at the end of year 1 and followed for an additional 1 year. Efficacy, therefore, was assessed in 2 groups, lorcaserin compared with placebo, in year 1 and 3 groups at the end of year 2, lorcaserin compared with placebo compared with lorcaserin-placebo. At the end of year 1 , lorcaserin resulted in $4.0 \%$ greater weight loss than placebo. A $\geq 5 \%$ weight loss from baseline body weight was achieved in $47.5 \%$ of subjects receiving lorcaserin compared with $20.3 \%$ receiving placebo. Only $22.6 \%$ of the lorcaserin group compared with $7.7 \%$ of the placebo maintained $\geq 10 \%$ weight loss from baseline. At the end of year 2, the degree of weight loss was maintained in the group continuing to receive lorcaserin, but weight gain was apparent in the group that was switched to placebo. The group that received lorcaserinplacebo had an identical weight loss to the placebo group by 28 weeks after the reassignment. ${ }^{50}$ There are no reported studies, either experimentally or from a meta-analysis, comparing the weight loss efficacy of lorcaserin with other medications for the treatment of obesity.

\section{Safety and tolerability}

Medications acting on serotonergic systems have received considerable scrutiny for cardiopulmonary complications because of the increased incidence of primary pulmonary hypertension and valvulopathies associated with earlier obesity medications, fenfluramine and dexfenfluramine. Sibutramine or lorcaserin has not been associated with any reported cases of confirmed pulmonary hypertension. In addition, pulmonary artery pressure has not been demonstrated to change with long-term treatment with either medication. ${ }^{50,155}$ Likewise, sibutramine has not been demonstrated to influence cardiac valve function or result in any evident valvulopathies. ${ }^{156}$ In a multicenter study examining weight loss efficacy of lorcaserin (see above), the occurrence of valvulopathy at 52 weeks was $2.7 \%$ in the subjects receiving lorcaserin $(10 \mathrm{mg}$ twice daily) and $2.3 \%$ in the placebo group. ${ }^{50}$ Preliminary findings at 52 weeks in the BLOOM-DM $(n=604)$ study for lorcaserin, however, have shown that the incidence of valvulopathies was $2.9 \%$ in subjects receiving lorcaserin $(10 \mathrm{mg}$ twice daily) and $0.5 \%$ in the placebo group. ${ }^{140}$ Although the study was not powered to determine a statistical difference in valvulopathies between groups, this almost 6-fold difference in incidence rates certainly raises concerns that likely need to be addressed in future lorcaserin studies. Notwithstanding, other documented safety issues and potential health risks have resulted in the withdrawal of sibutramine and the FDA rejection of lorcaserin.

At the time of FDA approval for sibutramine it was well demonstrated that the drug was associated with increased heart 
rate and blood pressure. Initially, the NDA for sibutramine contained 5 doses $(5 \mathrm{mg}, 10 \mathrm{mg}, 15 \mathrm{mg}, 20 \mathrm{mg}$, and $30 \mathrm{mg}$ once daily). Because of the potential dose-dependent cardiovascular risk balanced against the potential benefit for the treatment of obesity, only 3 doses $(5 \mathrm{mg}, 10 \mathrm{mg}$, and $15 \mathrm{mg}$ once daily) were approved by the FDA in $1997 .{ }^{152,157}$ Sibutramine, though, carries a bold-type warning that blood pressure and heart rate should be monitored in patients receiving the drug and it is contraindicated in individuals with a history of coronary artery disease, congestive heart failure, arrhythmias, or stroke. ${ }^{47}$ In a meta-analysis of 7 doubleblind randomized control studies examining sibutramine treatment ( $\geq 1$ year) in obese individuals, the drug was found to increase systolic blood pressure by $1.7 \mathrm{~mm} \mathrm{Hg}$, diastolic pressure by $2.4 \mathrm{~mm} \mathrm{Hg}$, and resting heart rate by $4.5 \mathrm{bpm}$ compared with placebo. ${ }^{17}$ The increase in heart rate and blood pressure is likely to influence cardiovascular function. The recently completed SCOUT trial was conducted in 16 countries, initially enrolling $>10,000$ subjects, to examine the long-term effects (mean treatment was 3.4 years) of sibutramine on cardiovascular outcomes in overweight and obese subjects. Unlike other clinical studies with sibutramine, eligible subjects had to have a history of cardiovascular disease and/or diabetes mellitus type II with one risk factor for cardiovascular disease. As previously demonstrated, sibutramine was associated with an increase in blood pressure and heart rate; the drug also resulted in an increased rate of nonfatal myocardial infarction $(+0.9 \%)$ and stroke $(+0.7 \%) .^{48}$ The most frequently reported adverse events with sibutramine are dry mouth, insomnia, and constipation. Typically, these events are dose-related, the $15 \mathrm{mg}$ dose having a placebo-subtracted reported frequency of $\sim 20 \%, \sim 5 \%$, and $\sim 5 \%$, respectively. ${ }^{47,152}$

The major safety concerns for the lorcaserin $(10 \mathrm{mg}$ twice daily) NDA are findings from the carcinogenicity studies in rodents. In particular, 2-year treatment with lorcaserin resulted in a higher combined incidence rate of mammary fibroadenomas and adenocarcinomas in female rats at the $10 \mathrm{mg} / \mathrm{kg}, 30 \mathrm{mg} / \mathrm{kg}$, and $100 \mathrm{mg} / \mathrm{kg}$ compared with vehicle-treated animals. In the male rats at the $30 \mathrm{mg} / \mathrm{kg}$ and $100 \mathrm{mg} / \mathrm{kg}$ doses, there was also a higher incidence rate of combined mammary tumors and skin benign fibromas. In addition, male rats receiving the $100 \mathrm{mg} / \mathrm{kg}$ dose showed an increased incidence rate of astrocytomas, squamous carcinomas, Schwannomas, combined hepatocullular neoplasms, and follicular cell adenomas. Over the 2-year study, the survival rate for both genders of rats was strongly negatively influenced by lorcaserin. In fact, the female survival rate was $18.4 \%$ for $10 \mathrm{mg} / \mathrm{kg}, 7.7 \%$ for $30 \mathrm{mg} / \mathrm{kg}$, and $0 \%$ for $100 \mathrm{mg} / \mathrm{kg}$ while the vehicle survival rate was $35 \%$. Only the high dose appeared to influence the survival rate of males, which was $5.3 \%$ compared with $33.8 \%$ of the vehicle group. Necropsy findings confirmed that lorcaserininduced tumors were associated with the excessive mortality observed with both genders of rats. ${ }^{51}$ In a multicenter phase III clinical trial with lorcaserin (10 $\mathrm{mg}$ twice daily) treatment ( $\geq 1$ year) the most frequently subject-reported adverse event was headache $(7.2 \%$ in lorcaserin compared with $4.3 \%$ in placebo). The frequency of headaches in the treated population, as well as other less frequent subject-reported adverse events, had a tendency to decrease with lorcaserin treatment length. ${ }^{50}$

Both sibutramine and lorcaserin appear to be well tolerated by obese subjects. The reported 1 -year attrition rate appears to be about $35 \%$ for sibutramine and about $45 \%$ for lorcaserin. ${ }^{17,50}$ Certainly more long-term studies are needed to determine accurate drop-out and nonresponder rates with lorcaserin.

\section{Patient-focused perspectives}

Improvements in the quality of life, attitudes, and mood have been demonstrated to occur in overweight or obese patients with weight loss. ${ }^{158-160}$ Long-term pharmacotherapy for obesity, including sibutramine and lorcaserin, at doses that are effective at reducing body weight are also associated with improvements in the quality of life and subjective attitude scores. ${ }^{17,50,161}$ What is unclear is whether the medications per se or the medication-associated additional weight loss is responsible for the improvement in quality of life and patient attitude. Experiments addressing this issue with sibutramine have had mixed findings. In one study ( $\mathrm{n}=376), 6$-month treatment with sibutramine $(10 \mathrm{mg})$ combined with highfrequency contact with a dietician resulted in greater weight loss than the group receiving sibutramine only. Although quality of life assessment was significantly improved from baseline (ie, before intervention and/or sibutramine), there was no difference in scores between groups. ${ }^{161}$ This implies that sibutramine treatment alone had an impact on quality of life not directly related to the degree of weight loss. In contrast, a 12-month study $(\mathrm{n}=236)$ in obese subject with diabetes mellitus type II, treatment with sibutramine (15 mg) produced significantly greater weight loss $(7.3 \%)$ than the placebo group $(2.4 \%)$, but did not change health-related quality of life ratings. ${ }^{162}$ Sibutramine $(15 \mathrm{mg})$ treatment compared with placebo for 6 months also failed to improve quality of life scores in a population of bulimic patients 
( $n=304)$, but effectively reduced body weight and reduced the severity and frequency of binge eating episodes. ${ }^{163}$

\section{Conclusion}

Pharmacotherapy would greatly benefit effective interventional nonsurgical strategies for the management of obesity. As a result of the US and European drug regulatory agencies scrutinizing more closely the approval and the continued use of these medications, the approved drug market for the treatment of obesity has been reduced to one medication, orlistat. Aside from the frequently reported gastrointestinal disturbances and the well-documented modest long-term drug-associated weight loss $(\sim 3 \%)$, orlistat is relatively safe. The continued approval of orlistat as a prescribed and over-the-counter treatment for obesity demonstrates that the weight-loss efficacy standards of the FDA and European regulatory agencies, $5 \%$ drug-associated weight loss and $>35 \%$ of the treated population losing $5 \%$ of body weight, are not a contingent criteria for drug approval. The rationale in orlistat's case is that any safe weight loss is beneficial. In order for drug manufacturers to develop and screen potential medications that receive approval by these agencies, the efficacy guidelines should be clearly revised to include the acceptable margin of drug-associated weight loss. In doing so and under the "any weight loss is beneficial" premise, this is likely to produce pharmacotherapy with reduced efficacy for weight loss, but with fewer and less severe adverse effects.

While drug regulatory agencies examine the risk-benefit analysis of each approved and proposed medication for the treatment of obesity, the unapproved herbal and "natural" dietary supplements consumer market is driven almost entirely by demand. In a study of 35,000 US adults approximately $34 \%$ had used dietary supplements for weight loss and approximately $50 \%$ of the entire sampled population overestimated the safety and efficacy of these unapproved weight loss supplements. ${ }^{164} \mathrm{Herbal}$ and dietary supplements reduce appetite and promote weight loss by various mechanisms, some of which are not clearly defined or systematically examined. ${ }^{165}$ A number of these supplements (eg, "bitter orange" and other stimulants) promote weight loss by increasing autonomic activity (including increases in resting heart rate and blood pressure). ${ }^{166,167}$ Unlike patients that received sibutramine, however, individuals taking dietary supplements are likely not being observed regularly by a health care provider to monitor heart rate and blood pressure. Indeed, the risk of nonfatal myocardial infarction and stroke has not been assessed with herbal remedies and dietary supplements used to suppress appetite. In the past, the FDA has been reactive, rather than proactive, in regulating diet supplements (eg, ephedra). Taken in the broader context of a demonstrated need and willingness of the consumer market for substances that promote weight loss and the availability of the unregulated alternatives, an argument can be made that withdrawal of sibutramine is likely to be more detrimental to the overweight and obese population than the risks associated with sibutramine treatment. Another option not exercised by the FDA and other regulatory agencies is to include a "black box" warning on sibutramine, which appears to be more than reasonable considering the medication has been on the US market for 13 years. The data from the SCOUT clinical trial should be considered "worst case scenario", since the primary outcome event was the incidence of nonfatal myocardial infarction, nonfatal stroke resuscitation after cardiac arrest, and cardiovascular death in subjects with a history of and/or risk factors for cardiovascular disease. What is also unclear is whether the cardiovascular risks associated with sibutramine are long lasting or permanent after cessation of sibutramine treatment. Overall, the rationale of the FDA for the withdrawal of sibutramine seems unwarranted and unnecessary considering the medication, certainly since its approval in 1997, has always been associated with increases in cardiovascular-related adverse effects.

In contrast, the decision of the FDA not to approve lorcaserin pending further data is entirely reasonable. The carcinogenicity findings in rats are too difficult to rectify without a defined mechanism of action, as is the related low survival rate. The low survival rate with lorcaserin is rather surprising considering that calorie restriction with weight loss decreases mortality and leads to a longer life span. ${ }^{168,169}$ A recent study re-examining the toxicology data from a 2-year study in rodents $(n=520$ mice and $n=520$ rats) found that sibutramine had no effect (either positive or negative) on longevity or mortality rate. ${ }^{170}$ In the toxicology studies with lorcaserin, on the other hand, the reduced survival rate trends exactly with the dose-dependent drug-induced tumor load, suggesting the cause of the increased mortality is likely a result of lorcaserin carcinogenicity. Further testing is undoubtedly needed to clearly determine whether the tumor burden was caused by lorcaserin or was related to toxicity as a result of the maximum tolerated dose being exceeded.

Therapeutically targeting the serotonergic systems will continue to be a viable approach for the treatment of obesity. This does not mean that other neurotransmitter systems or even combination therapies may prove to be more efficacious in combating obesity with fewer side effects. 
Even so, serotonin actions in producing subjective feelings of satiety by modulation of the neural mechanisms of appetite are beneficial not only for reducing and maintaining body weight, but also for controlling eating behavior. Because of the adverse effects associated with nonspecific serotonin drugs, such as dexfenfluramine and sibutramine, the recent direction of drug development has focused on specific receptor agonists. Recent findings with lorcaserin, the $5 \mathrm{HT}_{2 \mathrm{C}}$ agonist, need further clarification while a specific $5 \mathrm{HT}_{1 \mathrm{~B}}$ receptor agonist has yet to be clinically developed. Although the immediate hope for a serotonin-based pharmacotherapy seems remote, given what is known about the serotonin systems and the control of appetite, the long-term probability is that a new serotonin-based therapeutic will emerge. In the short-term, the landscape of obesity pharmacotherapy would be better served by a clarification of reasonable efficacy standards by regulatory agencies.

\section{Acknowledgment}

The authors would like to thank Kathy Manger for her editorial assistance in preparing the manuscript.

\section{Disclosure}

The authors have no conflict of interests to disclose.

\section{References}

1. Marcason W. What are the latest figures for state-specific prevalence of obesity in the United States? J Am Diet Assoc. 2007;107(1): 168.

2. Neufeld LM, Hernandez-Cordero S, Fernald LC, Ramakrishnan U. Overweight and obesity doubled over a 6-year period in young women living in poverty in Mexico. Obesity (Silver Spring). 2008;16(3): 714-717.

3. Zaninotto P, Head J, Stamatakis E, Wardle H, Mindell J. Trends in obesity among adults in England from 1993 to 2004 by age and social class and projections of prevalence to 2012. J Epidemiol Community Health. 2009;63(2):140-146.

4. Han JC, Lawlor DA, Kimm SY. Childhood obesity. Lancet. 2010:15;375 (9727):1737-1748.

5. Jafar TH, Qadri Z, Islam M, Hatcher J, Bhutta ZA, Chaturvedi N. Rise in childhood obesity with persistently high rates of undernutrition among urban school-aged Indo-Asian children. Arch Dis Child. 2008;93(5):373-378.

6. Popkin BM. Recent dynamics suggest selected countries catching up to US obesity. Am J Clin Nutr. 2010;91(1):284S-288S.

7. World Health Organization; Obesity and overweight fact sheet no. 311. WHO website. 2006. http://www.who.int/mediacentre/factsheets/ fs311/en/. Accessed February 4, 2011.

8. James WP. WHO recognition of the global obesity epidemic. Int J Obes (Lond). 2008;32 Suppl 7:S120-S126.

9. Ford ES, Mokdad AH, Giles WH, Galuska DA, Serdula MK. Geographic variation in the prevalence of obesity, diabetes, and obesityrelated behaviors. Obes Res. 2005;13(1):118-122.

10. Hursting SD, Berger NA. Energy balance, host-related factors, and cancer progression. J Clin Oncol. 2010;28(26):4058-4065.

11. Li F, Fisher KJ, Harmer P. Prevalence of overweight and obesity in older US adults: estimates from the 2003 Behavioral Risk Factor Surveillance System survey. J Am Geriatr Soc. 2005;53(4):737-739.
12. NHLBI Obesity Education Initiative. The Practical Guide Identification, Evaluation, and Treatment of Overweight and Obesity in Adults. $\mathrm{NIH}$ Publication No. 00-4084. 2000.

13. Mayor S. NICE requires primary care trusts to tackle prevention and management of obesity. BMJ. 2006;333(7581):1239.

14. Look AHEAD Research Group, Wing RR. Long-term effects of a lifestyle intervention on weight and cardiovascular risk factors in individuals with type 2 diabetes mellitus: four-year results of the Look AHEAD trial. Arch Intern Med. 2010;170(17):1566-1575.

15. Andersson C, Weeke P, Fosbol EL, et al. Acute effect of weight loss on levels of total bilirubin in obese, cardiovascular high-risk patients: an analysis from the lead-in period of the Sibutramine Cardiovascular Outcome trial. Metabolism. 2009;58(8):1109-1115.

16. Mertens IL, van Gaal LF. Overweight, obesity, and blood pressure: the effects of modest weight reduction. Obes Res. 2000;8(3): $270-278$.

17. Rucker D, Padwal R, Li SK, Curioni C, Lau DC. Long term pharmacotherapy for obesity and overweight: updated meta-analysis. BMJ. 2007;335(7631):1194-1199.

18. Mechanick JI, Kushner RF, Sugerman HJ, et al. American Association of Clinical Endocrinologists, The Obesity Society, and American Society for Metabolic and Bariatric Surgery Medical Guidelines for Clinical Practice for the perioperative nutritional, metabolic, and nonsurgical support of the bariatric surgery patient. Surg Obes Relat Dis. 2008;4(5 Suppl):S109-S184.

19. Fontana MA, Wohlgemuth SD. The surgical treatment of metabolic disease and morbid obesity. Gastroenterol Clin North Am. 2010;39(1): $125-133$.

20. Guller U, Klein LV, Hagen JA. Safety and effectiveness of bariatric surgery: Roux-en-Y gastric bypass is superior to gastric banding in the management of morbidly obese patients. Patient Saf Surg. 2009; $3(1): 10$.

21. Sjostrom L, Gummesson A, Sjostrom CD, et al. Effects of bariatric surgery on cancer incidence in obese patients in Sweden (Swedish Obese Subjects Study): a prospective, controlled intervention trial. Lancet Oncol. 2009;10(7):653-662.

22. Picot J, Jones J, Colquitt JL, et al. The clinical effectiveness and cost-effectiveness of bariatric (weight loss) surgery for obesity: a systematic review and economic evaluation. Health Technol Assess. 2009;13(41):1-190, 215-357, iii-iv.

23. Jensen C, Flum DR. The costs of nonsurgical and surgical weight loss interventions: is an ounce of prevention really worth a pound of cure? Surg Obes Relat Dis. 2005;1(3):353-357.

24. Salem L, Jensen CC, Flum DR. Are bariatric surgical outcomes worth their cost? A systematic review. J Am Coll Surg. 2005;200(2): 270-278.

25. Tindle HA, Omalu B, Courcoulas A, Marcus M, Hammers J, Kuller LH. Risk of suicide after long-term follow-up from bariatric surgery. Am J Med. 2010;123(11):1036-1042.

26. Basu A. Forecasting distribution of body mass index in the United States: is there more room for growth? Med Decis Making. 2010; 30(3):E1-E11.

27. Guidance for the clinical evaluation of weight-control drugs. Crit Rev Food Sci Nutr. 2001;41(1):91-94.

28. Hadvary P, Lengsfeld $\mathrm{H}$, Wolfer $\mathrm{H}$. Inhibition of pancreatic lipase in vitro by the covalent inhibitor tetrahydrolipstatin. Biochem J. 1988;256(2):357-361.

29. Ko J, Small DM. Behavior of tetrahydrolipstatin in biological model membranes and emulsions. J Lipid Res. 1997;38(8):1544-1552.

30. Davidson MH, Hauptman J, DiGirolamo M, et al. Weight control and risk factor reduction in obese subjects treated for 2 years with orlistat: a randomized controlled trial. JAMA. 1999;281(3): $235-242$.

31. Zhi J, Melia AT, Guerciolini R, et al. Retrospective population-based analysis of the dose-response (fecal fat excretion) relationship of orlistat in normal and obese volunteers. Clin Pharmacol Ther. 1994; 56(1):82-85. 
32. Hill JO, Hauptman J, Anderson JW, et al. Orlistat, a lipase inhibitor, for weight maintenance after conventional dieting: a 1-y study. $\mathrm{Am} \mathrm{J}$ Clin Nutr. 1999;69(6):1108-1116.

33. Filippatos TD, Derdemezis CS, Gazi IF, Nakou ES, Mikhailidis DP, Elisaf MS. Orlistat-associated adverse effects and drug interactions: a critical review. Drug Saf. 2008;31(1):53-65.

34. McClendon KS, Riche DM, Uwaifo GI. Orlistat: current status in clinical therapeutics. Expert Opin Drug Saf. 2009;8(6):727-744.

35. Connery TP. Orlistat over the counter: Is it worth it? BMJ. 2008; 336(7634):7.

36. EMA. European Medicines Agency. Questions and answers on the suspension of medicines containing sibutramine. EMA/H/A-107/1256. 2010. http://www.ema.europa.eu/docs/en_GB/document_library/ Referrals_document/Sibutramine_107/WC500094238.pdf. Accessed February 4, 2011.

37. Abbott to Voluntarily Withdraw Meridia ${ }^{\circledR}$ (Sibutramine) in the US. Press Release; 2010 Oct 8. http://www.abbott.com/global/url/pressRelease/ en_US/Press_Release_0908.htm. Accessed February 4, 2011.

38. McNeely W, Goa KL. Sibutramine. A review of its contribution to the management of obesity. Drugs. 1998;56(6):1093-1124.

39. Nelson DL, Gehlert DR. Central nervous system biogenic amine targets for control of appetite and energy expenditure. Endocrine. 2006; 29(1):49-60.

40. Heal DJ, Aspley S, Prow MR, Jackson HC, Martin KF, Cheetham SC. Sibutramine: a novel anti-obesity drug. A review of the pharmacological evidence to differentiate it from d-amphetamine and d-fenfluramine. Int J Obes Relat Metab Disord. 1998;22 Suppl 1:S18-S28; discussion S29.

41. Buckett WR, Thomas PC, Luscombe GP. The pharmacology of sibutramine hydrochloride (BTS 54 524), a new antidepressant which induces rapid noradrenergic down-regulation. Prog Neuropsychopharmacol Biol Psychiatry. 1988;12(5):575-584.

42. Rowley HL, Butler SA, Prow MR, et al. Comparison of the effects of sibutramine and other weight-modifying drugs on extracellular dopamine in the nucleus accumbens of freely moving rats. Synapse. 2000;38(2):167-176.

43. Wortley KE, Heal DJ, Stanford SC. Modulation of sibutramine-induced increases in extracellular noradrenaline concentration in rat frontal cortex and hypothalamus by alpha2-adrenoceptors. Br J Pharmacol. 1999;128(3):659-666.

44. Hauner H, Meier M, Wendland G, Kurscheid T, Lauterbach K. Weight reduction by sibutramine in obese subjects in primary care medicine: the SAT Study. Exp Clin Endocrinol Diabetes. 2004;112(4):201-207.

45. Smith IG, Goulder MA. Randomized placebo-controlled trial of long-term treatment with sibutramine in mild to moderate obesity. J Fam Pract. 2001;50(6):505-512.

46. Wooltorton E. Obesity drug sibutramine (Meridia): hypertension and cardiac arrhythmias. CMAJ. 2002;166(10):1307-1308.

47. Meridia (sibutramine hydrochloride monohydrate) capsules. [Package insert] Document 600-452107. 2010.

48. James WP, Caterson ID, Coutinho W, et al. Effect of sibutramine on cardiovascular outcomes in overweight and obese subjects. $N$ Engl J Med. 2010;363(10):905-917.

49. Lam DD, Przydzial MJ, Ridley SH, et al. Serotonin 5-HT2C receptor agonist promotes hypophagia via downstream activation of melanocortin 4 receptors. Endocrinology. 2008;149(3):1323-1328.

50. Smith SR, Weissman NJ, Anderson CM, et al. Multicenter, placebocontrolled trial of lorcaserin for weight management. $N$ Engl J Med. 2010;363(3):245-256.

51. Arena Pharmaceuticals. FDA Briefing Document; NDA 22529 Lorqess (lorcaserin hydrocloride) Tablets, $10 \mathrm{mg}$. 2010. http://www.fda.gov/ downloads/AdvisoryCommittees/CommitteesMeetingMaterials/Drugs/ EndocrinologicandMetabolicDrugsAdvisoryCommittee/UCM225631. pdf. Accessed February 4, 2011

52. FDA Issues Complete Response Letter for Lorcaserin New Drug Application. Press release from Arena Pharmaceuticals, Inc.; 2010 Oct 22. http://www.eisai.com/presskits/LorcaserinPDUFA.FINAL.pdf. Accessed February 4, 2011.
53. Rapport MM, Green AA, Page IH. Serum vasoconstrictor, serotonin; isolation and characterization. J Biol Chem. 1948;176(3):1243-1251.

54. Rapport MM, Green AA, Page IH. Crystalline Serotonin. Science. 1948;108(2804):329-330

55. Berger M, Gray JA, Roth BL. The expanded biology of serotonin. Annu Rev Med. 2009;60:355-366.

56. Lechin F, van der Dijs B, Hernandez-Adrian G. Dorsal raphe vs median raphe serotonergic antagonism. Anatomical, physiological, behavioral, neuroendocrinological, neuropharmacological and clinical evidences: relevance for neuropharmacological therapy. Prog Neuropsychopharmacol Biol Psychiatry. 2006;30(4):565-585.

57. Medeiros MA, Costa-e-Sousa RH, Olivares EL, Cortes WS, Reis LC. A reassessment of the role of serotonergic system in the control of feeding behavior. An Acad Bras Cienc. 2005;77(1):103-111.

58. De Fanti BA, Hamilton JS, Horwitz BA. Meal-induced changes in extracellular 5-HT in medial hypothalamus of lean $(\mathrm{Fa} / \mathrm{Fa})$ and obese (fa/fa) Zucker rats. Brain Res. 2001;902(2):164-170.

59. Ohliger-Frerking P, Horwitz BA, Horowitz JM. Serotonergic dorsal raphe neurons from obese zucker rats are hyperexcitable. Neuroscience. 2003;120(3):627-634.

60. Fetissov SO, Meguid MM. Serotonin delivery into the ventromedial nucleus of the hypothalamus affects differently feeding pattern and body weight in obese and lean Zucker rats. Appetite. 2010;54(2): 346-353.

61. Park S, Harrold JA, Widdowson PS, Williams G. Increased binding at 5-HT(1A), 5-HT(1B), and 5-HT(2A) receptors and 5-HT transporters in diet-induced obese rats. Brain Res. 1999;847(1):90-97.

62. Costa E, Groppetti A, Revuelta A. Action of fenfluramine on monoamine stores of rat tissues. Br J Pharmacol. 1971;41(1):57-64.

63. Blundell JE, Leshem MB. Central action of anorexic agents: effects of amphetamine and fenfluramine in rats with lateral hypothalamic lesions. Eur J Pharmacol. 1974;28(1):81-88.

64. Gotestam KG, Andersson BE. Self-administration of amphetamine analogues in rats. Pharmacol Biochem Behav. 1975;3(2): 229-233.

65. Ghosh MN, Parvathy S. Tolerance pattern of the anorexigenic action of amphetamines, fenfluramine, phenmetrazine and diethylpropion in rats. Br J Pharmacol. 1976;57(4):479-485.

66. Garattini S, Mennini T, Samanin R. From fenfluramine racemate to $\mathrm{d}$-fenfluramine. Specificity and potency of the effects on the serotoninergic system and food intake. Ann NY Acad Sci. 1987;499:156-166.

67. Vivero LE, Anderson PO, Clark RF. A close look at fenfluramine and dexfenfluramine. J Emerg Med. 1998;16(2):197-205.

68. Rothman RB, Baumann MH. Serotonin releasing agents. Neurochemical, therapeutic and adverse effects. Pharmacol Biochem Behav. 2002; 71(4):825-836.

69. Mennini T, Fracasso C, Cagnotto A, et al. In vitro and in vivo effects of the anorectic agent dexfenfluramine on the central serotoninergic neuronal systems of non-human primates. A comparison with the rat. Naunyn Schmiedebergs Arch Pharmacol. 1996;353(6): 641-647.

70. Blundell JE, Tombros E, Rogers PJ, Latham CJ. Behavioural analysis of feeding: implications for the pharmacological manipulation of food intake in animals and man. Prog Neuropsychopharmacol. 1980;4(4-5): 319-326.

71. Halford JC, Harrold JA, Boyland EJ, Lawton CL, Blundell JE. Serotonergic drugs:effects on appetite expression and use for the treatment of obesity. Drugs. 2007;67(1):27-55.

72. Boschmann M, Frenz U, Murphy CM, Noack R. Changes in energy metabolism and metabolite patterns of obese rats after application of dexfenfluramine. Pharmacol Biochem Behav. 1996;53(3): 549-558.

73. Bray GA. A concise review on the therapeutics of obesity. Nutrition. 2000;16(10):953-960.

74. Connolly HM, Crary JL, McGoon MD, et al. Valvular heart disease associated with fenfluramine-phentermine. NEngl J Med. 1997;337(9): 581-588. 
75. Teramae CY, Connolly HM, Grogan M, Miller FA Jr. Diet drug-related cardiac valve disease: the Mayo Clinic echocardiographic laboratory experience. Mayo Clin Proc. 2000;75(5):456-461.

76. Abenhaim L, Moride Y, Brenot F, et al. Appetite-suppressant drugs and the risk of primary pulmonary hypertension. International Primary Pulmonary Hypertension Study Group. N Engl J Med. 1996;335(9): 609-616.

77. Weintraub M, Sundaresan PR, Madan M, et al. Long-term weight control study. I (weeks 0 to 34). The enhancement of behavior modification, caloric restriction, and exercise by fenfluramine plus phentermine versus placebo. Clin Pharmacol Ther. 1992;51(5):586-594.

78. Weintraub M, Sundaresan PR, Schuster B, et al. Long-term weight control study. IV (weeks 156 to 190). The second double-blind phase. Clin Pharmacol Ther. 1992;51(5):608-614.

79. Weintraub M, Sundaresan PR, Schuster B, et al. Long-term weight control study. II (weeks 34 to 104). An open-label study of continuous fenfluramine plus phentermine versus targeted intermittent medication as adjuncts to behavior modification, caloric restriction, and exercise Clin Pharmacol Ther. 1992;51(5):595-601.

80. Weintraub M, Sundaresan PR, Schuster B, Moscucci M, Stein EC. Long-term weight control study. III (weeks 104 to 156). An open-label study of dose adjustment of fenfluramine and phentermine. Clin Pharmacol Ther. 1992;51(5):602-607.

81. FDA Announces Withdrawal Fenfluramine and Dexfenfluramine (Fen-Phen); 1997:P97-32.

82. Gundlah C, Martin KF, Heal DJ, Auerbach SB. In vivo criteria to differentiate monoamine reuptake inhibitors from releasing agents: sibutramine is a reuptake inhibitor. J Pharmacol Exp Ther. 1997;283(2):581-591.

83. Tao R, Fray A, Aspley S, Brammer R, Heal D, Auerbach S. Effects on serotonin in rat hypothalamus of D-fenfluramine, aminorex, phentermine and fluoxetine. Eur J Pharmacol. 2002;445(1-2): 69-81.

84. McGuirk J, Muscat R, Willner P. Effects of chronically administered fluoxetine and fenfluramine on food intake, body weight and the behavioural satiety sequence. Psychopharmacology (Berl). 1992;106(3): 401-407.

85. Halford JC, Wanninayake SC, Blundell JE. Behavioral satiety sequence (BSS) for the diagnosis of drug action on food intake. Pharmacol Biochem Behav. 1998;61(2):159-168.

86. Burton MJ, Cooper SJ, Popplewell DA. The effect of fenfluramine on the microstructure of feeding and drinking in the rat. BrJ Pharmacol. 1981;72(4):621-633.

87. Willner P, McGuirk J, Phillips G, Muscat R. Behavioural analysis of the anorectic effects of fluoxetine and fenfluramine. Psychopharmacology (Berl). 1990;102(2):273-277.

88. Blundell JE, Rogers PJ, Hill AJ. Behavioural structure and mechanisms of anorexia: calibration of natural and abnormal inhibition of eating. Brain Res Bull. 1985;15(4):371-376.

89. Tallett AJ, Blundell JE, Rodgers RJ. Sibutramine-induced anorexia: potent, dose-dependent and behaviourally-selective profile in male rats. Behav Brain Res. 2009;198(2):359-365.

90. Rogers PJ, Blundell JE. Effect of anorexic drugs on food intake and the micro-structure of eating in human subjects. Psychopharmacology (Berl). 1979;66(2):159-165.

91. Hill AJ, Blundell JE. Sensitivity of the appetite control system in obese subjects to nutritional and serotoninergic challenges. Int J Obes. 1990;14(3):219-233

92. Lawton CL, Wales JK, Hill AJ, Blundell JE. Serotoninergic manipulation, meal-induced satiety and eating pattern: effect of fluoxetine in obese female subjects. Obes Res. 1995;3(4):345-356.

93. Breisch ST, Zemlan FP, Hoebel BG. Hyperphagia and obesity following serotonin depletion by intraventricular p-chlorophenylalanine. Science. 1976;192(4237):382-385.

94. Saller CF, Stricker EM. Hyperphagia and increased growth in rats after intraventricular injection of 5,7-dihydroxytryptamine. Science. 1976;192(4237):385-387.
95. Auerbach SB, Lundberg JF, Hjorth S. Differential inhibition of serotonin release by 5-HT and NA reuptake blockers after systemic administration. Neuropharmacology. 1995;34(1):89-96.

96. Gundlah C, Hjorth S, Auerbach SB. Autoreceptor antagonists enhance the effect of the reuptake inhibitor citalopram on extracellular 5-HT: this effect persists after repeated citalopram treatment. Neuropharmacology. 1997;36(4-5):475-482.

97. Popa D, Cerdan J, Reperant C, et al. A longitudinal study of 5-HT outflow during chronic fluoxetine treatment using a new technique of chronic microdialysis in a highly emotional mouse strain. Eur $J$ Pharmacol. 2010:25;628(1-3):83-90.

98. Jackson HC, Bearham MC, Hutchins LJ, Mazurkiewicz SE, Needham AM, Heal DJ. Investigation of the mechanisms underlying the hypophagic effects of the 5-HT and noradrenaline reuptake inhibitor, sibutramine, in the rat. Br J Pharmacol. 1997;121(8): 1613-1618.

99. Jackson HC, Needham AM, Hutchins LJ, Mazurkiewicz SE, Heal DJ. Comparison of the effects of sibutramine and other monoamine reuptake inhibitors on food intake in the rat. $\mathrm{Br} J$ Pharmacol. 1997;121(8):1758-1762.

100. Faria AN, Ribeiro Filho FF, Kohlmann NE, Gouvea Ferreira SR, Zanella MT. Effects of sibutramine on abdominal fat mass, insulin resistance and blood pressure in obese hypertensive patients. Diabetes Obes Metab. 2005;7(3):246-253.

101. Astrup A. Macronutrient balances and obesity: the role of diet and physical activity. Public Health Nutr. 1999;2(3A):341-347.

102. Hansen DL, Toubro S, Stock MJ, Macdonald IA, Astrup A. The effect of sibutramine on energy expenditure and appetite during chronic treatment without dietary restriction. Int J Obes Relat Metab Disord. 1999;23(10):1016-1024.

103. Walsh KM, Leen E, Lean ME. The effect of sibutramine on resting energy expenditure and adrenaline-induced thermogenesis in obese females. Int J Obes Relat Metab Disord. 1999;23(10):1009-1015.

104. Connoley IP, Liu YL, Frost I, Reckless IP, Heal DJ, Stock MJ. Thermogenic effects of sibutramine and its metabolites. $\mathrm{Br} J$ Pharmacol. 1999;126(6):1487-1495.

105. Heusser K, Engeli S, Tank J, et al. Sympathetic vasomotor tone determines blood pressure response to long-term sibutramine treatment. J Clin Endocrinol Metab. 2007;92(4):1560-1563.

106. Heusser K, Tank J, Diedrich A, et al. Influence of sibutramine treatment on sympathetic vasomotor tone in obese subjects. Clin Pharmacol Ther. 2006;79(5):500-508.

107. Lechin F, van der Dijs B. Acute effects of sibutramine administration on the autonomic nervous system in obese subjects. Clin Pharmacol Ther. 2007;81(3):326; author reply 326-327.

108. Birkenfeld AL, Schroeder C, Boschmann M, et al. Paradoxical effect of sibutramine on autonomic cardiovascular regulation. Circulation. 2002;106(19):2459-2465.

109. Hoyer D, Hannon JP, Martin GR. Molecular, pharmacological and functional diversity of 5-HT receptors. Pharmacol Biochem Behav. 2002;71(4):533-554.

110. Hoyer D, Clarke DE, Fozard JR, et al. International Union of Pharmacology classification of receptors for 5-hydroxytryptamine (Serotonin). Pharmacol Rev. 1994;46(2):157-203.

111. Garfield AS, Heisler LK. Pharmacological targeting of the serotonergic system for the treatment of obesity. J Physiol. 2009;587(Pt 1): 49-60.

112. Banas SM, Doly S, Boutourlinsky K, et al. Deconstructing antiobesity compound action: requirement of serotonin 5-HT2B receptors for dexfenfluramine anorectic effects. Neuropsychopharmacology. 2011; 36(2):423-433.

113. Launay JM, Herve P, Peoc'h K, et al. Function of the serotonin 5-hydroxytryptamine $2 \mathrm{~B}$ receptor in pulmonary hypertension. Nat Med. 2002;8(10):1129-1135.

114. Nebigil CG, Hickel P, Messaddeq N, et al. Ablation of serotonin 5-HT(2B) receptors in mice leads to abnormal cardiac structure and function. Circulation. 2001;103(24):2973-2979. 
115. Mochizuki D, Yuyama Y, Tsujita R, Komaki H, Sagai H. Cloning and expression of the human 5-HT1B-type receptor gene. Biochem Biophys Res Commun. 1992;185(2):517-523.

116. Nothen MM, Erdmann J, Shimron-Abarbanell D, Propping P. Identification of genetic variation in the human serotonin 1D beta receptor gene. Biochem Biophys Res Commun. 1994;205(2): 1194-1200.

117. Bruinvels AT, Landwehrmeyer B, Gustafson EL, et al. Localization of 5-HT1B, 5-HT1D alpha, 5-HT1E and 5-HT1F receptor messenger RNA in rodent and primate brain. Neuropharmacology. 1994; 33(3-4):367-386.

118. Grignaschi G, Sironi F, Samanin R. The 5-HT1B receptor mediates the effect of d-fenfluramine on eating caused by intra-hypothalamic injection of neuropeptide Y. Eur J Pharmacol. 1995;274(1-3): 221-224.

119. Neill JC, Cooper SJ. Selective reduction by serotonergic agents of hypertonic saline consumption in rats: evidence for possible 5-HT1C receptor mediation. Psychopharmacology (Berl). 1989;99(2): 196-201.

120. Simansky KJ. Serotonergic control of the organization of feeding and satiety. Behav Brain Res. 1996;73(1-2):37-42.

121. Lee MD, Simansky KJ. CP-94, 253: a selective serotonin1B (5-HT1B) agonist that promotes satiety. Psychopharmacology (Berl). 1997; 131(3):264-270.

122. Lucas JJ, Yamamoto A, Scearce-Levie K, Saudou F, Hen R. Absence of fenfluramine-induced anorexia and reduced c-Fos induction in the hypothalamus and central amygdaloid complex of serotonin 1B receptor knock-out mice. J Neurosci. 1998;18(14):5537-5544.

123. Bouwknecht JA, van der Gugten J, Hijzen TH, Maes RA, Hen R, Olivier B. Male and female 5-HT(1B) receptor knockout mice have higher body weights than wildtypes. Physiol Behav. 2001;74(4-5): 507-516.

124. Elmquist JK, Ahima RS, Maratos-Flier E, Flier JS, Saper CB. Leptin activates neurons in ventrobasal hypothalamus and brainstem. Endocrinology. 1997;138(2):839-842.

125. Elmquist JK, Elias CF, Saper CB. From lesions to leptin: hypothalamic control of food intake and body weight. Neuron. 1999;22(2): 221-232.

126. Schwartz MW, Baskin DG, Kaiyala KJ, Woods SC. Model for the regulation of energy balance and adiposity by the central nervous system. Am J Clin Nutr. 1999;69(4):584-596.

127. Cone RD. Anatomy and regulation of the central melanocortin system. Nat Neurosci. 2005;8(5):571-578.

128. Heisler LK, Jobst EE, Sutton GM, et al. Serotonin reciprocally regulates melanocortin neurons to modulate food intake. Neuron. 2006;51(2):239-249.

129. Martin JR, Bos M, Jenck F, et al. 5-HT2C receptor agonists: pharmacological characteristics and therapeutic potential.J Pharmacol Exp Ther. 1998;286(2):913-924.

130. Kennett GA, Curzon G. Potencies of antagonists indicate that 5-HT1C receptors mediate 1-3(chlorophenyl)piperazine-induced hypophagia. Br J Pharmacol. 1991;103(4):2016-2020.

131. Tecott LH, Sun LM, Akana SF, et al. Eating disorder and epilepsy in mice lacking 5-HT2c serotonin receptors. Nature. 1995;374(6522): 542-546.

132. Vickers SP, Clifton PG, Dourish CT, Tecott LH. Reduced satiating effect of d-fenfluramine in serotonin 5-HT(2C) receptor mutant mice. Psychopharmacology (Berl). 1999;143(3):309-314.

133. Nonogaki K, Strack AM, Dallman MF, Tecott LH. Leptin-independent hyperphagia and type 2 diabetes in mice with a mutated serotonin 5-HT2C receptor gene. Nat Med. 1998;4(10):1152-1156.

134. Fletcher PJ, Tampakeras M, Sinyard J, Slassi A, Isaac M, Higgins GA. Characterizing the effects of 5-HT(2C) receptor ligands on motor activity and feeding behaviour in 5-HT(2C) receptor knockout mice. Neuropharmacology. 2009;57(3):259-267.
135. Heisler LK, Cowley MA, Tecott LH, et al. Activation of central melanocortin pathways by fenfluramine. Science. 2002;297(5581): 609-611.

136. Dalton GL, Lee MD, Kennett GA, Dourish CT, Clifton PG. Serotonin $1 \mathrm{~B}$ and $2 \mathrm{C}$ receptor interactions in the modulation of feeding behaviour in the mouse. Psychopharmacology (Berl). 2006;185(1):45-57.

137. Zhou L, Sutton GM, Rochford JJ, et al. Serotonin $2 \mathrm{C}$ receptor agonists improve type 2 diabetes via melanocortin-4 receptor signaling pathways. Cell Metab. 2007;6(5):398-405.

138. Hayashi A, Suzuki M, Sasamata M, Miyata K. Thermogenic effect of YM348, a novel 5-HT2C-receptor agonist, in rats. J Pharm Pharmacol. 2004;56(12):1551-1556.

139. Hayashi A, Suzuki M, Sasamata M, Miyata K. Agonist diversity in 5-HT(2C) receptor-mediated weight control in rats. Psychopharmacology (Berl). 2005;178(2-3):241-249.

140. Lorcaserin Phase 3 clinical trial in patients with type 2 diabetes shows statistically significant weight loss. Press Release Arena Pharmaceuticals. November 9, 2010.

141. Mancini MC, Halpern A. Pharmacological treatment of obesity. Arq Bras Endocrinol Metabol. 2006;50(2):377-389.

142. Zhou Z, Zhen J, Karpowich NK, Law CJ, Reith ME, Wang DN. Antidepressant specificity of serotonin transporter suggested by three LeuT-SSRI structures. Nat Struct Mol Biol. 2009;16(6): $652-657$.

143. Luscombe GP, Hopcroft RH, Thomas PC, Buckett WR. The contribution of metabolites to the rapid and potent down-regulation of rat cortical beta-adrenoceptors by the putative antidepressant sibutramine hydrochloride. Neuropharmacology. 1989;28(2):129-134.

144. Luscombe GP, Slater NA, Lyons MB, Wynne RD, Scheinbaum ML, Buckett WR. Effect on radiolabelled-monoamine uptake in vitro of plasma taken from healthy volunteers administered the antidepressant sibutramine HCl. Psychopharmacology (Berl). 1990;100(3): 345-349.

145. Bae SK, Cao S, Seo KA, et al. Cytochrome P450 2B6 catalyzes the formation of pharmacologically active sibutramine $(\mathrm{N}-\{1-[1-$ (4-chlorophenyl)cyclobutyl]-3-methylbutyl\}-N,N-dimethylamine) metabolites in human liver microsomes. Drug Metab Dispos. 2008; 36(8):1679-1688.

146. Padwal RS, Majumdar SR. Drug treatments for obesity: orlistat, sibutramine, and rimonabant. Lancet. 2007;369(9555):71-77.

147. Talbot PS, Bradley S, Clarke CP, et al. Brain serotonin transporter occupancy by oral sibutramine dosed to steady state: a PET study using (11) C-DASB in healthy humans. Neuropsychopharmacology. 2010;35(3):741-751.

148. Smith BM, Smith JM, Tsai JH, et al. Discovery and structure-activity relationship of (1R)-8-chloro-2,3,4,5-tetrahydro-1-methyl-1H-3benzazepine (Lorcaserin), a selective serotonin 5-HT2C receptor agonist for the treatment of obesity. $J$ Med Chem. 2008;51(2): 305-313.

149. Thomsen WJ, Grottick AJ, Menzaghi F, et al. Lorcaserin, a novel selective human 5-hydroxytryptamine $2 \mathrm{C}$ agonist: in vitro and in vivo pharmacological characterization. J Pharmacol Exp Ther. 2008; 325(2):577-587.

150. Smith SR, Prosser WA, Donahue DJ, Morgan ME, Anderson CM, Shanahan WR. Lorcaserin (APD356), a selective 5-HT(2C) agonist, reduces body weight in obese men and women. Obesity (Silver Spring). 2009;17(3):494-503.

151. Weintraub M, Rubio A, Golik A, Byrne L, Scheinbaum ML. Sibutramine in weight control: a dose-ranging, efficacy study. Clin Pharmacol Ther. 1991;50(3):330-337.

152. Bray GA, Blackburn GL, Ferguson JM, et al. Sibutramine produces dose-related weight loss. Obes Res. 1999;7(2):189-198.

153. Bray GA, Ryan DH, Gordon D, Heidingsfelder S, Cerise F, Wilson K. A double-blind randomized placebo-controlled trial of sibutramine. Obes Res. 1996;4(3):263-270. 
154. Hanotin C, Thomas F, Jones SP, Leutenegger E, Drouin P. A comparison of sibutramine and dexfenfluramine in the treatment of obesity. Obes Res. 1998;6(4):285-291.

155. Guven A, Koksal N, Cetinkaya A, Sokmen G, Ozdemir R. Effects of the sibutramine therapy on pulmonary artery pressure in obese patients. Diabetes Obes Metab. 2004;6(1):50-55.

156. Bach DS, Rissanen AM, Mendel CM, et al. Absence of cardiac valve dysfunction in obese patients treated with sibutramine. Obes Res. 1999;7(4):363-369.

157. FDA Recommends Against the Continued Use of Meridia (sibutramine). Questions and Answers. FDA press release. October 8, 2010.

158. Bond DS, Phelan S, Wolfe LG, et al. Becoming physically active after bariatric surgery is associated with improved weight loss and healthrelated quality of life. Obesity (Silver Spring). 2009;17(1):78-83.

159. Wing RR, Phelan S. Long-term weight loss maintenance. Am J Clin Nutr. 2005;82(1 Suppl):222S-225S.

160. Fine JT, Colditz GA, Coakley EH, et al. A prospective study of weight change and health-related quality of life in women. JAMA. 1999; 282(22):2136-2142.

161. Digenio AG, Mancuso JP, Gerber RA, Dvorak RV. Comparison of methods for delivering a lifestyle modification program for obese patients: a randomized trial. Ann Intern Med. 2009;150(4):255-262.

162. Kaukua JK, Pekkarinen TA, Rissanen AM. Health-related quality of life in a randomised placebo-controlled trial of sibutramine in obese patients with type II diabetes. Int J Obes Relat Metab Disord. 2004; 28(4):600-605.
163. Wilfley DE, Crow SJ, Hudson JI, et al. Efficacy of sibutramine for the treatment of binge eating disorder: a randomized multicenter placebo-controlled double-blind study. Am J Psychiatry. 2008;165(1): 51-58.

164. Pillitteri JL, Shiffman S, Rohay JM, Harkins AM, Burton SL, Wadden TA. Use of dietary supplements for weight loss in the United States: results of a national survey. Obesity (Silver Spring). 2008;16(4): 790-796.

165. Lenz TL, Hamilton WR. Supplemental products used for weight loss. J Am Pharm Assoc (2003). 2004;44(1):59-67; quiz 67-58.

166. Dwyer JT, Allison DB, Coates PM. Dietary supplements in weight reduction. J Am Diet Assoc. 2005;105(5 Suppl 1):S80-S86.

167. Bui LT, Nguyen DT, Ambrose PJ. Blood pressure and heart rate effects following a single dose of bitter orange. Ann Pharmacother. 2006; 40(1):53-57.

168. Carlson JC, Riley JC. A consideration of some notable aging theories. Exp Gerontol. 1998;33(1-2):127-134.

169. Merry BJ. Dietary restriction in rodents-delayed or retarded ageing? Mech Ageing Dev. 2005;126(9):951-959.

170. Smith DL Jr, Robertson HT, Desmond RA, Nagy TR, Allison DB. No compelling evidence that sibutramine prolongs life in rodents despite providing a dose-dependent reduction in body weight. Int $J$ Obes (Lond). Nov 16, 2010. [Epub ahead of print].
Drug Design, Development and Therapy

\section{Publish your work in this journal}

Drug Design, Development and Therapy is an international, peerreviewed open-access journal that spans the spectrum of drug design and development through to clinical applications. Clinical outcomes, patient safety, and programs for the development and effective, safe, and sustained use of medicines are a feature of the journal, which

\section{Dovepress}

has also been accepted for indexing on PubMed Central. The manuscript management system is completely online and includes a very quick and fair peer-review system, which is all easy to use. Visit http://www.dovepress.com/testimonials.php to read real quotes from published authors.

Submit your manuscript here: http://www.dovepress.com/drug-design-development-and-therapy-journal 